\title{
KEKUATAN HUKUM PUTUSAN DALAM PERKAWINAN CAMPURAN (BEDA AGAMA) (Studi Putusan No. 622/Pdt.P/2018/PN.Mks.)
}

\author{
Dian Zulfa Aklima1, Fauzah Nur Aksa², Ramziati ${ }^{3}$ \\ Email: fauzahnuraksa@gmail.com \\ ${ }^{1}$ Alumni Fakultas Hukum Universitas Malikussaleh \\ ${ }^{23}$ Dosen Fakultas Hukum Universitas Malikussaleh
}

\begin{abstract}
Perkawinan beda agama masih ditemukan di Indonesia dengan cara meminta penetapan pengadilan, sebagaimana dalam Putusan No. 622/Pdt.P/2018/ PN.Mks. dengan alasan bahwa para pemohon merasa bertanggung jawab terhadap anak yang lahir di luar perkawinan. Meskipun perkawinan beda agama telah mendapatkan izin Pengadilan Negeri serta telah diakui negara, namun perkawinan tersebut menyalahi aturan hukum sebagaimana pada Pasal 2 ayat (1) UU No. 1 tahun 1974 serta Pasal 40 huruf c dan Pasal 44 Kompilasi Hukum Islam. Hasil penelitian menunjukkan bahwa meskipun perkawinan beda agama telah mendapat izin pengadilan dan dicatatkan pada KCS, namun, persoalan ini belum jelas dari segi kepastian hukum terhadap anak dan cenderung menimbulkan permasalahan yang berkepanjangan terhadap anak, seperti status keabsahan sang anak yang dianggap sebagai anak yang tidak sah, kemudian pada kewajiban orang tua, hak waris, wali nikah serta pendidikan anak.
\end{abstract}

\section{Keywords:}

Kekuatan Hukum, Perkawinan Beda Agama, Putusan 


\section{A. PENDAHULUAN}

Pergaulan bebas memang telah menjalar dikalangan kaum muda, bahkan hampir tidak dapat dibedakan antara muslim dengan non muslim, karena pergaulan dengan lawan jenis baik yang seagama maupun berbeda agama bisa dikatakan hampir tidak ada batasan. Di kota besar, menjalin hubungan berdasarkan cinta kasih sudah menjadi suatu hal yang biasa pada saat sekarang ini, bahkan tanpa mempersoalkan pasangan tersebut seagama atau tidak.

Mereka menghalalkan berbagai cara demi meraih segala yang diinginkan tanpa peduli bahwa hal tersebut bertentangan dengan ajaran agama. Selain itu kurangnya kontrol dari keluarga, masyarakat serta lingkungan terhadap pergaulan bebas dikalangan kaum muda membuat mereka menjadi leluasa, misalnya ketika seorang muslimah berduaan dengan pria yang bukan mahramnya baik muslim maupun non muslim, maka keadaan sekitar seolah-olah biasa saja, bahkan kegiatan tersebut terkesan difasilitasi oleh keluarga, masyarakat dan lingkungan.

Dengan demikian, timbul dampak negatif seperti hamil di luar nikah antara muslimah dengan pria yang bukan mahramnya. Kondisi demikian mendorong mereka untuk melakukan pernikahan dengan pasangannya baik yang seagama maupun dengan pemeluk agama yang berbeda agar anak yang dikandung mendapat pengakuan secara hukum dan mendapat sosok orang tua yang utuh.

I Ketut Mandra dan I Ketut Artadi memaknai perkawinan beda agama yaitu ikatan lahir batin antara laki-laki dan perempuan yang berbeda agama dan menjaga perbedaan agamanya sebagai suami istri guna membentuk rumah tangga yang bahagia dan kekal berdasarkan Ketuhanan Yang Maha Esa.3 Adapun pada umumnya, makna perkawinan dari segi agama yaitu ikatan jasmani dan rohani yang mempunyai akibat hukum bagi agama dan keluarganya. (Andika, 2017)

Pada zaman penjajahan Belanda, perkawinan beda agama yakni diperbolehkan sebagaimana dalam ketentuan Pasal 7 ayat (2) GHR, bahwa perbedaan agama, suku atau keturunan sama sekali tidak menjadi kendala perkawinan. Namun dengan disahkannya UU Perkawinan pada tahun 1974, maka segala ketentuan yang mengatur kebolehan perkawinan beda agama tidak berlaku lagi. (Anshary, 2009)

Sebagaimana dinyatakan dalam UU Perkawinan bahwa dengan berlakunya UU ini, maka aturan yang ada dalam Kitab Undang- Undang Hukum Perdata (Burgerlijk Wetboek), Ordonansi Perkawinan Indonesia Kristen 
(Huwelijk Ordonantie Christen Indonesier S.1993 No. 74), Peraturan Perkawinan Campuran (Regeling Op De Gemengde Huwalijken S.1898 No. 158), dan aturan lainnya yang mengatur perkawinan sejauh telah diatur dalam undang-undang ini, dinyatakan tidak berlaku.

Pasal 1 Undang-Undang No.

1 Tahun 1974 mengatur tentang makna perkawinan sebagai ikatan lahir batin antara seorang pria dengan seorang wanita sebagai suami istri dengan tujuan membentuk keluarga (rumah tangga) yang bahagia dan kekal berdasarkan Ketuhanan Yang Maha Esa. Kemudian Pasal 2 ayat (1) UU No. 1 Tahun 1974 menyatakan bahwa perkawinan adalah sah apabila dilakukan menurut hukum masingmasing agama dan kepercayaannya. Makna dari masing-masing agama yakni memiliki keimanan yang sama atau agama yang sama, misalnya perkawinan antara muslim dengan muslim, Kristen dengan Kristen dan lain sebagainya.

Selain Undang Undang di atas, Perpres Nomor 1 Tahun 1991 Tentang Kompilasi Hukum Islam (KHI), disebutkan pada Pasal 40 huruf c bahwa dilarang melangsungkan perkawinan antara seorang pria dengan seorang wanita yang tidak beragama Islam. Kemudian Pasal 44 KHI juga mengatur bahwa seorang wanita Islam dilarang melangsungkan perkawinan dengan seorang pria yang tidak beragama Islam. Namun pada kenyataannya masih ditemukan adanya perkawinan beda agama dengan meminta penetapan pengadilan, sebagaimana pada Putusan No. 622/Pdt.P/2018/PN.Mks. antara seorang laki-laki Kristen Protestan dengan seorang perempuan Islam. Keduanya ingin membangun rumah tangga melalui sebuah ikatan perkawinan, salah satu alasan utama para pemohon yang bersangkutan mengajukan permohonannya ke pengadilan yakni para pemohon merasa bertanggung jawab atas anak yang lahir di luar perkawinan.7 Pasal 1 ayat (12) UU No. 35 Tahun 2014 Tentang Perubahan atas UU No. 23 Tahun 2002 Tentang Perlindungan Anak menyatakan bahwa alasan hak anak perlu dilindungi ialah karena merupakan bagian dari hak asasi manusia yang wajib dilindungi dan dipenuhi oleh orang tua, keluarga, masyarakat, negara, pemerintah dan pemerintah daerah.

Meskipun perkawinan beda agama telah mendapatkan izin dari Pengadilan Negeri serta telah diakui oleh negara karena dicatatkan pada Kantor Catatan Sipil, namun perkawinan tersebut menyalahi aturan hukum sebagaimana dalam ketentuan Pasal 2 ayat (1) UU No. 1 Tahun 1974 serta Pasal 40 huruf c dan Pasal 44 Kompilasi Hukum Islam (KHI). Berdasarkan latar 
belakang yang telah diuraikan, maka permasalahan hukum yang akan dibahas dalam kajian ini adalah sebagai berikut: Apakah pertimbangan hakim terhadap perkawinan beda agama pada Putusan No.622/Pdt.P/2018/ PN.Mks?. Bagaimanakah akibat hukum terhadap anak dari perkawinan beda agama berdasarkan penetapan hakim dalam Putusan No.622/Pdt.P/ 2018/PN.?

\section{B. METODE PENELITIAN}

Jenis penelitian yang digunakan ialah penelitian hukum normatif, pendekatan yang dilakukan yaitu pendekatan kasus, sifat penelitian yaitu desriptif, teknik pengumpulan data yaitu studi kepustakaan, bahan hukum yang digunakan yakni bahan hukum primer (UU No. 1 Tahun 1974, KHI, UU No. 35 tahun 2014, Penetapan Pengadilan No. 622/Pdt.P/2018/PN.Mks), bahan sekunder (karya ilmiah, RUU, buku oleh para ahli dst) dan tersier (kamus hukum, bibliografi dst) serta teknik analisis data melalui 3 tahapan yakni reduksi data (mengolah data mentah), penyajian data (data yang telah diolah menjadi sebuah informasi) dan penarikan kesimpulan (intisari).

\section{PEMBAHASAN}

\section{Pertimbangan Hakim Terhadap Perkawinan Beda Agama Pada Putusan No. 622/Pdt.P/2018/PN.Mks.}

Dalam amar putusan, hakim menetapkan bahwa hakim mengabulkan permohonan pemohon. Hal yang menjadi dasar pertimbangan hakim dalam memutuskan perkara perkawinan beda agama ialah didasarkan pada alasan para pemohon yang merasa bertanggung jawab atas anak yang lahir di luar perkawinan, sehingga para pemohon perlu melindungi hak anaknya, karena pada hakikatnya anak berhak mendapatkan perlindungan hukum. Untuk memperoleh gambaran yang luas mengenai pertimbangan hakim dalam memutuskan perkara, maka penulis merangkum hal yang menjadi pertimbangan hakim menjadi 3 bagian yakni pertimbangan sosiologis, pertimbangan yuridis dan pertimbangan administratif kenegaraan.

1.1 Pertimbangan Sosiologis

Unsur sosiologis merupakan unsur yang harus memberi manfaat baik kepada pihak yang berperkara maupun masyarakat. (Amran, 2018) Dalam pertimbangannya, hakim menilai bahwa ada WNI yang ingin menikah beda agama, namun tidak ada regulasi yang mengatur, 
sehingga menimbulkan kekosongan hukum atas kebutuhan sosial yang akan bermuara pada penyeludupan nilai-nilai sosial, agama atau penyeludupan nilai hukum.

Oleh karena itu, hal ini menjadi salah satu alasan hakim dalam mengabulkan perkawinan beda agama, karena di satu sisi ada kepentingan anak yang harus dilindungi ketika sang anak menjalani kehidupan sosial bermasyarakat. Sehingga jika dilihat dari unsur sosiologis, pada dasarnya putusan hakim tersebut telah memberi manfaat bagi para pemohon, yakni jika perkawinannya sah dan diakui, maka anak akan memperoleh hak dan kewajibannya secara utuh dari kedua orang tuanya.

Dari uraian di atas, terlihat bahwa tujuan hakim mengabulkan perkawinan tersebut salah satunya ialah untuk melindungi hak-hak anak, namun perkawinan beda agama justru menimbulkan perdebatan baik dikalangan praktisi hukum, pemuka agama maupun masyarakat lainnya. Melindungi anak merupakan kewajiban setiap pihak, akan tetapi upaya yang dilakukan untuk melindungi anak tidak boleh bertentangan dengan aturan yang diatur oleh UU di Indonesia saat ini, yakni dengan mengacu pada UU Perkawinan, karena pada hakikatnya pemberian izin terhadap perkawinan beda agama ialah tidak ada dasar hukum yang kuat untuk membenarkan hal- hal yang dilarang. 1.2 Pertimbangan Yuridis Unsur yuridis adalah pertimbangan atau alasan yang menunjukan bahwa peraturan yang dibuat untuk menyelesaikan masalah hukum atau untuk mengisi kekosongan hukum dengan memperhatikan aturan yang ada. (Sovia, 2020) Dalam pertimbangannya, hakim menyatakan bahwa pemohon sangat menginginkan terlaksananya perkawinan dan hal tersebut harus dihargai, karena merupakan bagian dari Hak Asasi Manusia (HAM).

Berdasarkan pertimbangan hakim di atas, hakim menyebutkan bahwa perkawinan beda agama harus dihargai, karena merupakan bagian dari Hak Asasi Manusia (HAM), jika dikaji pada Pasal 10 ayat (1) UU No. 39 Tahun 1999 Tentang HAM, bahwa setiap orang berhak untuk berkeluarga dan melanjutkan keturunan melalui keturunan yang sah. Kemudian ayat (2) menyatakan bahwa perkawinan yang sah hanya dapat berlangsung atas kehendak bebas calon suami dan calon isteri yang bersangkutan, sesuai dengan ketentuan peraturan perundangundangan. Hal ini terlihat bahwa HAM membatasi kebebasan seseorang untuk menikah beda agama karena bertentangan dengan hukum, karena hak asasi manusia harus mematuhi batasan hukum. 
Sebagaimana menurut Maria Farida Indrati. (Shanti, 2020) bahwa hak asasi manusia bisa dibatasi, sepanjang ada hukum yang mengaturnya.

Selain itu, dalam putusannya hakim juga mendalilkan bahwa hakim mengacu pada ketentuan Putusan MA No. 1400K/Pdt/1986 yang menyatakan bahwa dalam UU No. 1 Tahun 1974 jo PP No. 9 Tahun 1975 tidak ada peraturan yang menyatakan bahwa perbedaan agama antara calon suami istri merupakan larangan perkawinan. Oleh sebab itu, menurut hakim telah terjadi kekosongan hukum atas kebutuhan sosial yang dikhawatirkan akan menimbulkan praktek penyeludupan nilai sosial maupun agama, maka perkawinan beda agama harus ditemukan hukumnya. Dalam Putusan MA No. 1400K/Pdt/1986, hakim Mahkamah Agung membatalkan penetapan Pengadilan Negeri yang menolak melangsungkan perkawinan beda agama,13 sehingga pada prakteknya, yurisprudensi tersebut sering digunakan sebagai alasan para hakim dalam mengabulkan permohonan bagi para pihak yang ingin melangsungkan perkawinan beda agama, seperti dalam Putusan No. 622/Pdt.P/2018/PN.Mks. yang juga memberikan izin terhadap perkawinan tersebut.

Dalam penafsiran yang digunakan, UU Perkawinan hanya mengatur mengenai perkawinan campuran antar warga negara saja, sebagaimana dalam Pasal 57 UU No. 1 Tahun 1974, bahwa makna perkawinan campuran di dalam UU ini ialah perkawinan antara dua orang di Indonesia yang terikat oleh hukum yang berbeda karena perbedaan kewarganegaraan dan salah satunya berkewarganegaraan Indonesia.

Dalam sejarah lahirnya UU perkawinan, Muhammad Daud Ali mengemukakan bahwa perkawinan beda agama pernah dimasukan dalam RUU Perkawinan, namun karena tidak sesuai dengan prinsip pancasila, maka perkawinan beda agama dikeluarkan dari RUU Perkawinan. Meskipun demikian, UU Perkawinan telah mengatur secara tersirat terkait larangan perkawinan beda agama. sebagaimana dalam Pasal 2 ayat (1) UU No. 1 Tahun 1974 yang menyatakan bahwa perkawinan adalah sah apabila dilangsungkan menurut agama dan kepercayaannya masing-masing. Pasal tersebut bermakna bahwa maksud dari hukum masing-masing agama yakni jika ada pihak yang ingin melangsungkan perkawinan, maka harus merujuk pada ketentuan agamanya masingmasing. Selain itu, Pasal 8 huruf $\mathrm{f}$ UU No. 1 Tahun 1974 juga terdapat larangan perkawinan beda agama, pasal tersebut menyatakan bahwa perkawinan dilarang diantara dua 
orang yang mempunyai hubungan yang oleh agamanya atau peraturan lain yang berlaku dilarang kawin.

Dalam Islam tentunya sudah diatur mengenai larangan perkawinan beda agama yakni sebagaimana dalam QS. Al-Baqarah ayat 221 dan QS. Al Mumtahanah ayat 10. Kemudian juga pada Pasal 40 huruf c dan Pasal 44 KHI. Begitu juga dalam pandangan Kristen Protestan juga melarang perkawinan beda agama sebagaimana dalam Korintus Pasal 6 ayat 14. Alasannya jelas, bahwa tidak ada agama yang mengharapkan penganutnya tidak sejalan, karena secara tidak langsung perkawinan beda agama akan menghadapkan npemeluk agama itu sendiri untuk memilih antara tuhan dengan makhluk, sehingga hal tersebut akan berujung tidak baik.

\subsection{Pertimbangan Administratif Kenegaraan \\ Unsur administratif} kenegaraan adalah unsur yang berkaitan dengan administrasi negara yang merupakan bagian dari tata kelola atau yang biasa disebut good governance. (Rifdan, 2017) Contoh bentuk administratif kenegaraan ialah pencatatan nikah, yang tujuannya agar perkawinan diakui dan dilindungi oleh negara, karena selain keabsahan perkawinan, pencatatan perkawinan juga sangat diperlukan untuk tegaknya tata kelola pemerintah yang baik.
Dalam pertimbangan hakim pada Putusan No. 622/Pdt.P/2018/PN. Mks. hakim menyatakan bahwa pencatatan perkawinan bagi para pemohon dapat dilakukan di KCS, dengan alasan bahwa hakim merujuk pada Pasal 35 UU No. 23 Tahun 2006 Tentang Administrasi Kependudukan yang menyatakan bahwa pencatatan perkawinan berlaku bagi perkawinan yang ditentukan oleh pengadilan. Hakim menafsirkan bahwa yang dimaksud dengan perkawinan yang ditentukan oleh pengadilan adalah perkawinan yang dilangsungkan antar umat yang berbeda agama. Selain Pasal 35 UU No. 23 Tahun 2006, hakim juga merujuk pada ketentuan Putusan MA No. 1400k/Pdt/1986 yang menegaskan bahwa tidak ada alasan untuk menolak permohonan pemohon yang ingin melangsungkan perkawinan beda agama, karena pada kasus Putusan MA No. 1400k/Pdt/1986 salah satu pemohon tidak mengikuti aturan pada agamanya, sehingga perkawinan tersebut berhak dicatatkan di KCS. Dalam hal ini pada kasus Putusan No. 622/Pdt.P/2018/PN.Mks. hakim juga berpendapat bahwa perkawinan dapat dicatatkan di KCS namun perkawinan tidak dilaksanakan baik secara Islam maupun Kristen.

Jika ditinjau menurut Pasal 2 ayat (2) UU No. 1 Tahun 1974 bahwa tiap-tiap perkawinan dicatat 
menurut hukum dan peraturan yang berlaku. Maksud dari peraturan yang berlaku yakni suatu pencatatan perkawinan harus mengikuti persyaratan dan prosedur yang telah ditetapkan. Adapun pencatatan perkawinan dapat dilakukan apabila perkawinan telah dilangsungkan menurut agama dan kepercayaannya masing-masing. (Usman, 2017) Hal tersebut dapat dikatakan bahwa pencatatan perkawinan dapat dilaksanakan apabila suatu perkawinan telah dinyatakan sah secara agama, sehingga antara Pasal 2 ayat (1) dan Pasal 2 ayat (2) saling berkaitan antara satu sama lainnya.

Dari uraian di atas, pada dasarnya perkawinan beda agama tidak boleh dicatatkan di KCS, karena perkawinan beda agama tidak sesuai dengan aturan yang berlaku, seperti aturan yang ada pada UU No. 1 Tahun 1974 tentang Perkawinan jo PP No. 9 Tahun 1975 tentang Peraturan Pelaksana UU No. 1 Tahun 1974 Tentang Perkawinan, karena dengan diberikannya izin terhadap perkawinan tersebut, belum ada kepastian hukum terhadap anak dan perkawinan beda agama seringkali menimbulkan masalah jangka panjang bagi anak. Meskipun pada Putusan di atas ditetapkan bahwa perkawinan tidak dilaksanakan baik secara Islam maupun Kristen. Namun dapat diketahui bahwa para pemohon masih mengakui dan tunduk pada agamanya masing-masing, sehingga seharusnya mereka mengikuti aturan yang ada pada agamanya, agar terpenuhi syarat-syarat perkawinan yang telah ditentukan pada masingmasing agama, agar suatu perkawinan dapat dikatakan sah dan tidak menimbulkan suatu problematika.

Akibat Hukum Terhadap Anak Dari Perkawinan Beda Agama Berdasarkan Penetapan Hakim Dalam Putusan No. 622/Pdt.P/2018/ PN.Mks.

\section{Pengertian Akibat Hukum}

Akibat hukum merupakan suatu yang disebabkan oleh peristiwa hukum. Misalnya dalam putusan pengadilan tentang perkawinan beda agama, dengan adanya izin terhadap perkawinan tersebut, maka menimbulkan akibat hukum, salah satunya ialah bagi anak, karena perkawinan beda agama merupakan suatu peristiwa hukum yang telah diakui oleh negara dengan cara dicatatkan pada kantor catatan sipil.

2.1 Akibat Hukum Terhadap Anak Menurut UU No. 1 Tahun 1974 Tentang Perkawinan

Status Anak Berdasarkan Keabsahan Perkawinan Status perkawinan sangat menentukan status anak sah maupun tidak sah. Pada kasus perkawinan beda agama dapat diketahui bahwa perkawinan semacam ini tidak sah secara agama 
dan sifatnya hanya dicatat pada Kantor Catatan Sipil saja, dalam artian bahwa perkawinan tersebut dilaksanakan hanya secara sipil, namun tidak diakui oleh agama terhadap keabsahannya. Sebagaimana pada Putusan No. 622/Pdt.P/2018/PN.Mks, yang hanya mencatatkan perkawinannya, tetapi tidak dilaksanakan baik secara Islam maupun Kristen Protestan. Maka anak yang dilahirkan ialah merupakan anak yang tidak sah, karena dalam hal ini, sebagaimana menurut Pasal 42 UU No. 1 Tahun 1974 menyatakan bahwa anak yang sah adalah anak yang lahir dari atau sebagai akibat perkawinan yang sah. Sedangkan anak luar kawin sebagaimana dalam ketentuan Pasal 43 ayat (1) hanya akan mempunyai hubungan perdata dengan ibunya dan keluarga ibunya. Dalam hal ini meskipun perkawinan orang tuanya diakui oleh negara, namun secara hukum agama hal tersebut tidak dapat mengubah status anak menjadi anak yang sah.

\subsection{Kewajiban Orang Tua Terhadap Anak}

Pasal 45 ayat (1) UU No. 1 Tahun 1974 menyatakan bahwa kedua orang tua wajib memelihara dan mendidik anak dengan sebaikbaiknya. Kemudian ayat 2 menyatakan bahwa kewajiban orang tua yang dimaksud pada ayat (1) berlaku sampai anak itu kawin/dapat berdiri sendiri, kewajiban mana berlaku terus meskipun perkawinan antara kedua orang tua putus. Hilman Hadikusuma menyatakan bahwa dengan lahirnya anak, maka akan terjalin hak dan kewajiban antara orang tua dan anak-anaknya. Seorang ayah memiliki kewajiban memelihara dan mendidik anaknya, sedangkan ibu hanya berkewajiban menyusui anak dan merawatnya. (Hasan, 2016)

Namun, hak pemeliharaan terhadap anak yang dimiliki oleh orang tua hanya akan diperoleh apabila orang tuanya memiliki status perkawinan yang sah. Sedangkan perkawinan beda agama ialah merupakan perkawinan yang tidak sah, Sehingga segala pemenuhan hak-hak terhadap anak disandarkan kepada ibu dan keluarga ibu sebagaimana yang diatur pada Pasal 43 ayat (1) UU Perkawinan.

Pasal 43 ayat (1) UUP mendapat pertentangan dengan alasan bahwa hal tersebut merupakan suatu bentuk diskriminasi pada anak luar kawin, sebagaimana menurut Murtadla Muntahhari bahwa Pasal 43 ayat (1) bertentangan dengan konsep keadilan. (Farahi, 2020) Hal tersebut tidak tercermin pada Pasal 43 ayat (1), yang hanya membebankan hak-hak anak luar kawin pada ibu dan keluarga ibu. Sehingga Mahkamah Konstitusi (MK) melakukan uji materil terhadap Pasal 43 ayat (1) dengan kesimpulan 
bahwa anak luar kawin berhak memperoleh nafkah, hadhonah, perwalian dalam perkawinan serta warisan selama ayahnya dapat dibuktikan secara ilmu pengetahuan atau lainnya. (Farahi, 2020)

Akan tetapi dengan dikeluarkannya Putusan MK No. 46/PUU- VIII/2010 menimbulkan kontroversi dalam masyarakat, terutama MUI yang berpandangan bahwa dengan dilegalkannya aturan tersebut, akan memberikan peluang untuk berzina. Sehingga MUI mengeluarkan fatwanya dalam fatwa MUI No.11 Tahun 2012 tentang kedudukan anak zina dan perlakuan terhadapnya (Nurul, 2018), yang kemudian penulis simpulkan isinya bahwa kewajiban orang tua terhadap anak luar kawin, terutama kewajiban ayah biologis yakni dapat diberikan sanksi terhadap perbuatannya dengan hanya sebatas mencukupi kebutuhan sang anak, dan hal tersebut dapat dikatakan adil bagi pelaku zina, sedangkan untuk aturan yang menjadikan anak memiliki hubungan nasab dengan ayahnya dan keluarga ayahnya sebagaimana pada putusan MK di atas, maka menurut penulis hal tersebut tidak tepat, karena bertentangan dengan aturan dasar yang mengatur mengenai anak zina.

\subsection{Akibat Hukum Terhadap Anak Menurut Kompilasi Hukum Islam (KHI)}

Keabsahan Anak Menurut Kompilasi Hukum Islam (KHI) Dalam Kompilasi Hukum Islam (KHI), tidak jauh berbeda dengan ketentuan UU No. 1 Tahun 1974 yang mengatur mengenai kedudukan anak yang sah maupun anak yang tidak sah. Sebagaimana dalam Pasal 100 KHI menyatakan bahwa anak yang lahir di luar perkawinan hanya memiliki hubungan nasab dengan ibunya dan keluarga ibunya. Dalam hal ini tidak ada upaya yang dapat dilakukan untuk menjadikan anak tersebut sah. Karena perkawinan diantara kedua orang tuanya jelas merupakan larangan dalam perkawinan. Sebagaimana dalam Pasal 44 KHI menyatakan bahwa seorang wanita Islam dilarang melangsungkan perkawinan dengan seorang pria yang bukan beragama Islam.

\subsection{Akibat Hukum Terhadap Wali Nikah}

Pasal 20 KHI, memberikan pengertian wali nikah adalah lakilaki yang memenuhi syarat hukum Islam, yakni muslim, 'aqil dan baliq. Wali nikah terbagi menjadi 2 bagian yakni wali nasab dan wali hakim. wali nasab sebagaimana dalam Pasal 21 KHI ialah wali yang erat kekerabatannya dengan calon mempelai wanita, baik berdasarkan jenis keturunan ke atas maupun ke bawah. Sedangkan wali hakim sebagaimana dalam Pasal 22 KHI 
ialah wali yang bertindak apabila wali nasab tidak ada atau tidak mungkin menghadirkannya. Menurut Ali Yahya Abi Zakaria al-Anshari dalam bukunya Fathul Wahab, bahwa hak perwalian dapat dihalangi oleh budak, anak-anak, gila, fasiq, pikun dan berbeda agama. Namun apabila wali aqrabnya buta, sakit pitam atau sedang ihram, maka wali ab'ad (wali hakim) tidak boleh menikahkan anak tersebut, melainkan menunggu sembuhnya atau kembalinya wali aqrab.

Berdasarkan uraian di atas pada kasus perkawinan beda agama, jika pasangan tersebut memiliki anak perempuan dan anak tersebut memilih agama Islam, dan kemudian ingin menikah, maka anak perempuan tersebut tidak boleh diwalikan kepada ayah biologisnya maupun keluarga ayahnya. Karena wali nikahnya ialah berbeda keyakinan, sehingga dalam hal ini wali yang bertindak untuk menikahkan anak tersebut ialah wali hakim dengan alasan bahwa tidak mungkin wali aqrab dapat dihadirkan karena berbeda keyakinan beragama antara wali aqrab dan anak.

\subsection{Akibat HukumTerhadap Hak Mewaris}

Pasal 171 huruf c KHI menyatakan bahwa ahli waris adalah orang yang pada saat meninggal dunia mempunyai hubungan darah/ perkawinan dengan pewaris, dengan syarat beragama Islam dan tidak terhalang oleh hukum untuk menjadi pewaris. Secara umum, hal-hal yang dapat menjadi penghambat warisan terbagi menjadi 3 bagian, yakni pembunuhan, beda agama dan perbudakan. Arti bahwa beda agama dapat menghambat warisan adalah tidak ada hak saling mewarisi antara orang Islam dengan orang kafir (non muslim), orang Islam tidak mewarisi harta orang non muslim, begitu juga sebaliknya. Sebagaimana sabda Rasululah yang artinya, "tidaklah berhak seorang muslim mewarisi orang kafir dan tidak pula orang kafir mewarisi orang muslim (HR. Bukhari dan Muslim).

Undang-Undang telah mengatur bahwa dalam perkawinan beda agama, anak hanya mempunyai hubungan keperdataan dengan ibu dan keluarga ibu, sebagaimana yang tercantum dalam UU No. 1 Tahun 1974 maupun Kompilasi Hukum Islam. Dengan demikian, anak berhak atas harta ibunya. Namun jika anak berpindah keyakinan dan mengikuti agama ayahnya, maka anak tidak berhak atas harta warisan dari ibu, karena ia terhalang untuk menerima warisan.

\section{KESIMPULAN}

Berdasarkan hasil analisis data penelitian yang telah dilakukan, dapat disimpulkan bahwa: Hal yang menjadi dasar pertimbangan hakim dalam memutus perkara terbagi 
menjadi 3 bagian yaitu pertimbangan sosiologis (unsur manfaat), yakni bagi para pemohon demi kepentingan anak, kemudian pertimbangan yuridis, bahwa UU tidak mengatur larangan perkawinan beda agama, sementara menurut hakim perkawinan tersebut harus dihargai oleh HAM, selain itu pertimbangan administratif kenegaraan, yakni perkawinan tersebut dapat dicatatkan dengan merujuk pada ketentuan Pasal 35 a UU adminduk dan Putusan MA No. 1400k/Pdt/1986. Namun meskipun demikian, putusan tersebut masih keliru, karena setiap agama melarang adanya perkawinan beda agama. Sehingga terdapat ketidaksesuaian antara putusan hakim dengan aturan agama.

Akibat hukum terhadap anak dengan diizinkannya perkawinan beda agama yakni berakibat terhadap status keabsahan sang anak yang dianggap sebagai anak yang tidak sah. Kemudian berakibat pada kewajiban orang tua terhadap anak selanjutnya berakibat pada wali nikah sang anak yang tidak dibenarkan bahwa wali nikah nya berbeda keyakinan, begitu juga halnya dengan hak mewaris. Serta berakibat pada pendidikan sang anak yang cenderung membuat anak bingung terhadap agama yang akan dipilihnya karena faktor kedua orang tuanya berbeda keyakinan.

\section{DAFTAR PUSTAKA}

Amran Suadi, 2018, Sosiologi Hukum (Penegakan, Realitas dan Moralitas Hukum), Kencana, Jakarta Timur.

Andika Prawira Buana, 2017, Konsistensi Pengaruh Implementasi Undang- Undang No. 1 Tahun 1974 Tentang Perkawinan Terhadap Praktek Perkawinan Agama di Makassar, Jurnal HAM, Vol. 8, No. 2,https://ejournal.balitbangham.go.id /index.php/ham/article/view/319.

Ahmad Farahi dan Ramadhita, 2016, Keadilan Bagi Anak Luar Kawin dalam Putusan MK No. 46/PUUVIII/2010, Jurnal Hukum dan Syari'ah, Vol. 8, No. 2, EISSN:2528-1658, diakses melalui http://ejournal.uin-

malang.ac.id/index.php/syariah/articl e/view/3778.

Ilyas, 2015, Kedudukan Ahli Waris Non Muslim Terhadap Harta Warisan Pewaris Islam ditinjau dari Hukum Islam dan Kompilasi Hukum Islam, Kanun Jurnal Ilmu Hukum, No. 65, diakses melalui http://www.jurnal.unsyiah.ac.id/kanu n/article/download/6058/4992.

Khairi Ayumi Hasan, 2016, Thesis, Pertanggungjawaban Orang Tua Terhadap Anak Incest Menurut Hukum Islam, Fakultas Hukum Universitas Sumatera Utara Medan, diakses melalui http://repository.usu.ac.id/handle/ $123456789 / 65372$. 
Mardalena Hanifah, 2019, Perkawinan Beda Agama ditinjau dari UU No. 1 Tahun 1974 Tentang Perkawinan, Soematera Law Review, Volume 2, No. 2, E-ISSN: 26205904, diakses melalui http://ejournal.lldikti10.id

/index.php/soumlaw/article/view/442 0/1557.

Merli Ummu Khila, 2019, Yuk Taaruf, Jawa Timur, Uwais Inspirasi Indonesia.

Moh. Taufiqur Rohman, 2011, Perkawinan Campuran dan Perkawinan Antar Agama di Indonesia, Jurnal Al-Ahwal, Vol. 4, No.1, http://ejournal.uinsuka.ac.id/syariah/Ahwal/article/vie w/04103.

M. Anshary, 2009, Hukum Perkawinan di Indonesia, Aceh Utara, Pustaka Pelajar.

Nur Albaniyah, Pergaulan Remaja Tanpa Batas, Salah Siapa?, https://m.https://www.hidayatullah.c om/artikel/opini/read/2014/10/26/32 020/pergau lan-remaja-tanpa-batassalah-siapa.html, diakses pada tanggal 5 Januari 2020.

Nurul Hak, 2018, Kedudukan dan Hak Anak Luar Nikah Pasca Putusan MK No. 46/PUU-VIII/2010 Tentang Status Anak Luar Kawin, Jurnal Hukum, Ekonomi dan Keagamaan,Vol. 5, No. 2, diakses melalui

https://ejournal.iainbengkulu.ac.id/in dex.php/mizani/article/view/1441.
Rifdan dan Muhammadong, 2017, Tata Kelola Pencatatan Perkawinan, Makassar, Badan Penerbit UNM.

Shanti Rachmadsyah, HAM dan Kebebasan Beragama di Indonesia,https://www.hukumonline. com/klinik/detail/ulasan/c16556/hamdan- kebebasan-beragama-diindonesia, diakses Pada Tanggal 15 November 2020.

$\begin{array}{llc}\text { Sovia } & \text { Hasanah, } & \text { Arti } \\ \text { Landasan } & \text { Filosofis, } & \begin{array}{r}\text { Sosiologis } \\ \text { Yuridis, }\end{array}\end{array}$
https://www.hukumonline.com/klini k/detail/1t59394de7562ff/arti$\underline{\text { landasan }}$-filosofis--sosiologis--danyuridis/ diakses Pada 30 November 2020. 